Abstract P158 Table 1 Treatment comparisons for \% patients with $\geq 50 \%$ symptom free nights over the study duration

\begin{tabular}{|c|c|c|c|}
\hline $\begin{array}{l}\text { HZA106827 (Weeks 1-12) } \\
\text { REF }\end{array}$ & $\begin{array}{l}\text { Placebo } \\
(n=203)\end{array}$ & $\begin{array}{l}\text { FF } 100 \\
(n=204)\end{array}$ & $\begin{array}{l}\text { FF/VI } 100 \\
(n=201)\end{array}$ \\
\hline$\%$ of patients & $35 \%$ & $46 \%$ & $59 \%$ \\
\hline Odds Ratio $(95 \% \mathrm{Cl})$ & & $\begin{array}{l}\text { FF vs } \mathrm{PbO}: \\
2.29 \\
(1.41,3.73)\end{array}$ & $\begin{array}{l}\mathrm{FF} / \mathrm{NI} \text { vs } \mathrm{PbO}: \\
4.66 \\
(2.84,7.66)\end{array}$ \\
\hline Odds Ratio $(95 \% \mathrm{Cl})$ & & & $\begin{array}{l}\text { FF/VI vs } \\
\text { FF 100: } \\
2.04 \\
(1.29,3.22)\end{array}$ \\
\hline $\begin{array}{l}\text { Time (days) when } 50 \% \text { of } \\
\text { patients } \\
\text { achieved } 7 \text { nights without } \\
\text { symptoms }\end{array}$ & $\begin{array}{l}\text { Did not occur } \\
\text { during study }\end{array}$ & 70 & 44 \\
\hline HZA106863 (Weeks 1-12) & FF 100 & FF/VI 100 & FF/VI 200 \\
\hline REF & $(n=346)$ & $(n=345)$ & $(n=345)$ \\
\hline$\%$ of patients & $42 \%$ & $43 \%$ & $48 \%$ \\
\hline Odds Ratio $(95 \% \mathrm{Cl})$ & & $\begin{array}{l}\text { FF/VI } 100 \text { vs } \\
\text { FF } 100: \\
1.33 \\
(0.93,1.91)\end{array}$ & $\begin{array}{l}\text { FF/NI } 200 \text { vs } \\
\text { FF/NI } 100: \\
1.23 \\
(0.87,1.74)\end{array}$ \\
\hline $\begin{array}{l}\text { Time (days) when } 50 \% \text { of } \\
\text { patients } \\
\text { achieved } 7 \text { nights without } \\
\text { symptoms }\end{array}$ & 86 & 64 & 48 \\
\hline HZA106829 (Weeks 1-24) & FF 200 & FF/VI 200 & FP 500 \\
\hline REF & $(n=193)$ & $(n=197)$ & $(n=195)$ \\
\hline$\%$ of patients & $41 \%$ & $51 \%$ & $46 \%$ \\
\hline Odds Ratio (95\% Cl) & & $\begin{array}{l}\text { FF/VI } 200 \text { vs } \\
\text { FF } 200: \\
1.59 \\
(0.99,2.55)\end{array}$ & \\
\hline Odds Ratio $(95 \% \mathrm{Cl})$ & & $\begin{array}{l}\text { FF/VI } 200 \text { vs } \\
\text { FP } 500: \\
1.09 \\
(0.69,1.74)\end{array}$ & \\
\hline $\begin{array}{l}\text { Time (days) when } 50 \% \text { of } \\
\text { patients achieved } 7 \text { nights } \\
\text { without symptoms }\end{array}$ & 111 & 72 & 84 \\
\hline
\end{tabular}

\section{P159 THERAPEUTIC BENEFIT OF MEPOLIZUMAB IN THE SCOTTISH MEDICINES CONSORTIUM (SMC) RESTRICTED SUB-POPULATION - A POST-HOC META-ANALYSIS OF PHASE IIB/III TRIALS}

${ }^{1}$ RA Mehta, ${ }^{2}$ CEA Hartmann, ${ }^{2} \mathrm{NB}$ Gunsoy, ${ }^{1} \mathrm{FC}$ Albers. ${ }^{1}$ GlaxoSmithKline, Research Triangle Park, USA; ${ }^{2}$ GlaxoSmithKline, Uxbridge, UK

\subsection{6/thoraxjnl-2016-209333.302}

Rationale The Scottish Medicines Consortium provides advice to NHS boards and Area Drug and Therapeutics Committees across Scotland about the status of newly licensed medicines. In June 2016 positive advice was issued for mepolizumab, an anti-IL-5 $\mathrm{mAb}$ licensed for adult severe refractory eosinophilic asthma, for use in a restricted sub-population: patients who have eosinophils of $\geq 150$ cells per microlitre $(0.15 \times 109 / \mathrm{L})$ at initiation of treatment and had $\geq 4$ asthma exacerbations in the preceding year or are receiving maintenance treatment with oral corticosteroids
(mOCS). Here we present the results for this sub-population comparing the effect of mepolizumab with placebo in this subgroup.

Methods Three randomised, double-blind, placebo-controlled studies of mepolizumab in severe eosinophilic asthma were identified, which used the licensed $100 \mathrm{mg}$ SC dose or the corresponding $75 \mathrm{mg}$ IV dose of mepolizumab. For analysis purposes, these two treatment arms were combined. A post-hoc meta-analysis assessing the key outcome measures in the three phase IIb/III trials (DREAM [NCT01000506] and MENSA [NCT01691521] with a sensitivity analysis including SIRIUS [NCT01691508]) were run for the sub-population using individual patient data.

Results The post-hoc meta-analysis included 197 patients from DREAM and MENSA and 251 when including the SIRIUS trial. The mean age was 51.2 and 51.3 years of which $62 \%$ and $64 \%$ were female, respectively. A 59\% (95\% CI: $0.31,0.55$; $\mathrm{p}<0.001)$ reduction in clinically significant exacerbations was seen in the meta-analysis of DREAM and MENSA (50\% [95\% CI: $0.40,0.64, p<0.001]$ sensitivity analysis with SIRIUS). The ACQ score showed an improvement of $-0.56 \quad(95 \%$ CI: $-0.79,-0.33 ; \mathrm{p}<0.001$ ) and -0.58 (95\% CI: $-0.79,-0.38$; $\mathrm{p}<0.001$, sensitivity analysis with SIRIUS). The SGRQ was only used in MENSA and SIRIUS and showed an improvement in total score of $-8.0(-12.0,-3.9, \mathrm{p}<0.001)$.

Conclusion Mepolizumab treatment was effective in SMC advice population (adult severe refractory eosinophilic asthma patients with a blood eosinophil count of $\geq 150$ cells $/ \mu \mathrm{L}$ at initiation of treatment, and $\geq 4$ exacerbations in the previous year or dependency on mOCS). The use of a post-hoc meta-analysis is a helpful approach to increase our understanding of mepolizumab's treatment effect in the SMC restricted sub-population.

Funding GSK (NCT01000506, NCT01691521, NCT01691508).

\section{P160 USE OF OMALIZUMAB IN FUNGAL ALLERGIC ASTHMA}

${ }^{1} \mathrm{HV}$ Patel, ${ }^{2} \mathrm{~B}$ Kane, ${ }^{2} \mathrm{P}$ Foden, ${ }^{2} \mathrm{~L}$ Holmes, ${ }^{2} \mathrm{GOG}$ Tavernier, ${ }^{1} \mathrm{~TB}$ Morris, ${ }^{2} \mathrm{DM}$ Ryan, ${ }^{2}$ RM Niven. 'University of Manchester, Manchester, UK; ${ }^{2}$ University Hospital of South Manchester, Manchester, UK

10.1136/thoraxjnl-2016-209333.303

Background The monoclonal anti-IgE agent Omalizumab holds an established place in the management of severe allergic asthma patients (GINA Step 5). Fungal allergic asthma possesses added complexity as fungi are ubiquitous in our environment and are capable of not only triggering asthma, but may grow, colonise and infect host tissue. Current treatment approaches include: Allergen avoidance, mucus reduction, control of bacterial infection, control of inflammation, reducing fungal burden and recently blockade of allergy using Omalizumab.

Aims/purpose Investigate the response to Omalizumab in severe asthma patients who are sensitised to fungal allergens compared to those who are non-fungal allergic. Current literature describes the use of Omalizumab in fungal allergic airways disease, though published data takes the form of case reports/series with limited total population.

Methods Retrospective cohort study of severe asthma patients treated with Omalizumab $(n=168)$. Patients were grouped into fungal or non-fungal allergy status, followed by a comparison of the change in a variety of clinical and physiological outcomes at 16 weeks and 52 weeks from baseline between these two groups. The change in Asthma Quality of Life Questionnaire (AQLQ) between baseline and 16 weeks was utilised as the primary outcome. Groups will be compared using an unpaired t-test or Chi- 